\title{
The Nature of Hubristic Motivation and Development of Hubristic Syndrome through the Prism of Conflict
}

\section{Природа губристичної мотивації та розвитку губристичного синдрому крізь призму конфлікту}

Kateryna Bragina

Postgraduate Student in Psychology Department

\section{Катерина Брагіна}

аспірантка спеціальності 053

«Психологія»

E-mail: fox.minstrel@gmail.com

https://orcid.org/0000-0002-9314-2432

Researcher ID: D-2403-2019

Lesya Ukrainka Eastern

European National University,

Lutsk, Ukraine

13, Voli Avenue, Lutsk,

Volyn region, 43025
Східноєвропейський національний університет

імені Лесі Українки, м. Луиьк, Украӥна просп. Волі, 13, м. Луцьк, Волинська область, 43025

Original manuscript received February 24, 2019 Revised manuscript accepted March 29, 2019

\section{ABSTRACT}

The article shows the theoretical research of the nature of the hubristic motivation as a component of personality and theoretical investigation of the possibility of its implementation through the prism of conflict. The problem is relevant in the context of human interaction and communication, because hubristic traits such as cynicism, selfishness, ambition or cunning, form a vital part of any personality and despite the stereotypes the ignoring them is im- 
possible. Sometimes it is even harmful to humans because it causes internal conflict and leads to increased psychological stress. The article analyzes the current views on hubristic desire and their influence on self-perception. The theoretical approach carried out the review of the problem of conflict and development of personality. The features of manifestation of negative features of character and formation of a hubristic syndrome as a destructor of interpersonal interaction and adequate perception of the world are described, a comparative analysis with a narcissistic syndrome and erosion of the power are carried out. In the article there have been given the main symptoms of the hubristic syndrome, variations of its manifestation and ways of its prevention. The article shows the nature of psychological homeostasis and its manifestation in people with an expressed desire for power and a desire for selfdevelopment. The advantages of reducing the tension by getting a person into a conflict, including provoking it consciously or unconsciously, as well as the danger posed to the person by hidden negative aspects of the character are considered in the theoretical research. In the article the examples of manifestations of hubristic desires in social interaction, including childhood are given. The article shows the connection between the desire of getting the power and the desire of self-realization with the tendency of a person to enter into conflict. Also the importance to argue for the sake of preventing the growth of frustration through unrealized hubristic motivation is described. The theoretical review proves the need for further study of this problem at the practical level, since in the modern world the character traits are still considered as a negative phenomenon that must be controlled and suppressed.

Key words: hubristic motivation, hubristic qualities, conflict, homeostasis, hubris syndrome, narcissistic disorder.

\section{Вступ}

Губристична мотивація як прагнення до підвищення своєї самооцінки є вагомим i природним бажанням особистості, оскільки зумовлює її активність до саморозвитку i самоствердження. На сучасному етапі уникнути конфліктів неможливо, оскільки усвідомлене задоволення губристичних бажань особистості потребує від неї вибору способу, як цього можна досягти. Крім того, необхідне проведення адекватної оцінки щодо досяжності своїх бажань, своєї здатності мобілізувати мотивацію, інтелектуальні ресурси та поведінкові зусилля на їх реалізацію, прогнозу- 
вання наслідків від прийнятого рішення, а за необхідності - здійснення відповідного впливу на перебіг подій, від яких залежить задоволення губристичних бажань особистості. Однак гіпертрофована форма реалізації мотиву самоствердження за принципом вищості або як компенсація іншої фрустрованої потреби можуть призвести до так званого губристичного синдрому, котрий не лише змінює погляди людини на спілкування та соціум, а й призводить до пошуку компенсації відчуття неповноцінності, посилення бажання впливати на поведінку інших людей тощо. 3 цього випливає припущення, що губристична мотивація та конфлікт є двома пов' язаними між собою явищами.

Мета статті полягає у теоретичному узагальненні матеріалу щодо природи губристичної мотивації й окресленні шляхів розвитку губристичного синдрому в межах конфлікту.

\section{Завдання статті}

1. Здійснити теоретичний огляд наукових джерел із проблеми губристичної мотивації у сучасній психології.

2. Проаналізувати основні симптоми губристичного синдрому та детермінанти його прояву.

3. Розкрити важливість перебування у конфлікті для людей із яскраво вираженою губристичною мотивацією.

\section{Методи дослідження}

Для досягнення поставленої мети використовувались теоретичні методи аналізу, синтезу, узагальнення.

\section{Результати та дискусії}

Згідно з Ю. Козелецьким, губристична мотивація - це прагнення людини до самоствердження, підвищення своєї самооцінки та значущості (Козелецький, 1991). Це не просто бажання отримати владу - особистість із вираженим прагненням до переваги хоче досягнути вершини досконалості. Самоствердження є природним і основним рушієм 
активності особистості та регулятором її діяльності (Фоменко, 2017). Важливою умовою реалізації губристичної мотивації є конфлікт, який дає змогу людині зменшити рівень психологічного напруження та стресу, краще зрозуміти оточуючих і розкритись самій, отримати важливий соціальний досвід і дати оцінку своїм силам (Орлянський, 2007).

Проте це не єдиний спосіб задовольнити губристичні бажання. Окрім влади, людина може прагнути й до реалізації себе як особистості, як майстра своєї справи та фахівця, який повністю володіє власними ресурсами. У цьому випадку людина починає відточувати свої уміння та розвивати здібності, випробовує себе у різних галузях, у неї з'являються нові хобі. Проте такі, здавалось би, позитивні цілі не виключають задіяння людиною негативних аспектів у гонитві за бажаним. Прагнучи стати видатним спортсменом, людина може вдаватись до хитрощів або ж обману, наприклад, не повідомляючи важливу або доносячи хибну інформацію про змагання. Особистість, керована бажанням стати найкращою і досягнути влади, у своїй поведінці не цуратиметься застосування будь-яких методів, навіть якщо вони соціально неприйнятні.

Важливо й те, що розуміння губристичних рис - амбіційності, гордині, заздрощів, самовпевненості - може різнитись залежно від умов, у яких зростала людина. Якщо в сім’ї дитині казали, що ціль виправдовує засоби, то, звісно, у дитини може сформуватись установка, що такі риси характеру, як амбіційність чи гординя, є нормальними та прийнятними. Інша ситуація може скластись, коли дитина росте неамбіційною, що, в свою чергу, може призвести до безпорадності або ж упевненості у відсутності в себе сил досягати бажаного.

Окремі губристичні риси, наприклад цинізм, можуть слугувати механізмом захисту - на думку А. Блазера, він є способом людини захистити себе від жорстокості оточуючих або ж мінімізувати значущість недосяжного об’єкта 
(Blaser, 1976). В авраамічних релігіях такі людські риси, як гординя, нарцисизм, егоїзм або ж хитрість, вважаються неприйнятними, що зумовило негативне ставлення людей до подібних якостей характеру. Проте подібне відношення не виключає важливості їх наявності, а тим більше прояву, в особистості.

Варто зазначити, що високий рівень губристичної мотивації не дає людині перебувати в гомеостазі, адже статичність не дозволяє рухатись до цілі та змушує людину перебувати у стані фрустрації через неможливість задовольнити свої прагнення. Губристичній особистості необхідно постійно реалізувати бажання влади навіть на побутовому рівні. Зупиняючись у пошуках свого місця в соціумі, людина відчуває дискомфорт, адже відсутність змін для неї означає відсутність руху, а, отже, і розвитку. Для виходу з психологічного гомеостазу такій особистості необхідно потрапити в екстремальну ситуацію або ж у ту, котра потребує великих затрат енергії й активності. Це можуть бути імпульсивні вчинки або ті дії, під час яких людина ризикує власним життям.

Проте реалізувати губристичні прагнення можна і простішим способом, наприклад, провокуючи конфлікт. Хтось удається до цього свідомо, розуміючи, що має на меті створення конфліктної ситуації задля підкріплення своєї самооцінки та підвищення особистої значущості шляхом реалізації амбіційності. Деякі ж люди несвідомо потрапляють у конфліктну ситуацію. Коли людині вдається звільнитися від напруження, викликаного губрисом, задовольнити своє бажання влади, реалізувавши його шляхом вирішення конфліктної ситуації, відбувається досягнення мети підкріплення власної самооцінки, втрачається потреба у продовженні конфлікту (Козьяков, 2012). Якщо ж уникнути напруження не вдалося, оскільки людина не досягла своєї мети - підкріплення власної самооцінки, то посилюється відчуття дискомфорту через виникнення неспроможності досягнення бажаного, що й змушує особистість знову 
і знову повторювати спробу реалізації своїх губристичних прагнень за допомогою конфлікту.

Згадане раніше явище гомеостазу є не просто періодом стабільності в житті людини - це баланс між внутрішнім і зовнішнім світом. Його важливість описував З̊. Піаже, стверджуючи, що активність, яку суб’єкт спрямовує на досягнення гомеостазу, забезпечує його розвиток (Piaget, 1969). Це природне явище, котре можна відслідкувати не лише в психології, а й фізіології. Гомеостаз гармонізує функціонування організму людини як відкритої системи і забезпечує рівновагу між нею й оточуючим середовищем (Саркисов, 1977). Проте для осіб із сильним бажанням підкріплювати свою важливість постійний гомеостаз може спричиняти дискомфорт. Чим сильніше виражені у характері особистості такі риси, як гординя чи самовпевненість, тим важче пережити період подібного застою. Для утворення і розвитку мотивації людині необхідно виходити з такого стану, адже лише динаміка і зміна умов перебування можуть допомогти поставити нові цілі. Наприклад, згідно з теорією К. Левіна мотивація та бажання діяти виникають тоді, коли зовнішні й внутрішні поля знаходяться в дисонансі та не можуть збалансуватись (Lewin, 1951). Отже, не дивлячись на важливу роль явища гомеостазу в психіці людини, постійний баланс і стабільність може гальмувати іiі бажання до розвитку та роботи над собою.

Варіантів виходу з гомеостазу може бути безліч. Саме тому, свідомо чи несвідомо, людина розпочинає конфлікт або стає його учасником. Іноді її погляди можуть навіть збігатись із думками та принципами опонента, проте бажаючи зменшити психологічне напруження, викликане нереалізованим бажанням самоствердитись, особистість удається до цілеспрямованого провокування конфлікту задля задоволення губристичних прагнень у переважанні над іншими. Цей процес не стільки деструктивний, як природний і необхідний людині для підтримання своїх губристичних бажань у такому стані, який не викликатиме 
дискомфорт. У той час, як одній людині легко вдається переживати періоди спокою, інша може прагнути постійних змін. Ситуації, що провокують викид адреналіну, дають змогу не лише реалізувати губристичні риси, а й відточити вже існуючі навички, розвинути вміння планувати свої дії та прогнозувати відповіді опонента.

Конфлікт змушує людину витрачати свої ресурси, знижує емоційний тонус і є доволі виснажливим процесом (Козьяков, 2012). Його природність, як і варіативність характерів людей, робить конфлікт неминучим явищем, котре не вдасться проігнорувати (Ващенко, 2012). Теоретико-методологічні аспекти дослідження конфлікту та конфліктності особистості розглядаються авторами Л. А. Онуфрієвою та В. I. Співаком (Онуфрієва \& Співак, 2015). Саме тому навіть людям із низьким рівнем губристичної мотивації варто відточувати своє вміння правильно поводитись під час конфліктів. Під цим розуміється координація своїх дії задля мінімізації шкоди для себе й оточуючих. Уникнення конфлікту далеко не завжди є найкращою тактикою, іноді краще вступити у відкриту конфліктну взаємодію задля відстоювання своєї думки.

Сам же конфлікт дає змогу не лише вивільнити губристичну енергію - він є варіантом реалізації людини як особистості. Це дозволяє відчути ту владу, до якої прагне людина, керована бажанням підкріпити свою самооцінку. Якщо ж ціллю людини є не стільки влада, скільки пошук себе у світі та соціумі, то вміння переживати конфлікт забезпечить швидше досягнення своїх прагнень, оскільки на шляху до самореалізації уникнути зіткнення інтересів і думок неможливо.

Конфлікт не лише дає людині можливість утримувати губристичні бажання на оптимальному рівні й контролювати їх, а й сприяє розвитку гнучкості, отриманню нового досвіду, яким можна скористатися під час реалізації губристичних прагнень. Важливим чинником при цьому є здатність людини приймати іншу думку, визнавати свою 
неправоту та здійснювати перегляд цінностей. Якщо губристична мотивація знаходиться на оптимальному рівні, то зробити це набагато легше. Оптимальний рівень характеризується вмінням об’єктивно оцінити поведінку іншої людини, вміти програвати та залежно від ситуації визнавати свою неправоту. Це доволі важко для особистості 3 високим рівнем губристичної мотивації, особливо якщо в їі характері домінує гординя, адже поразка змушує їі почуватися слабкою. Це негативне та деструктивне відчуття, оскільки гординя не просто не дозволяє людині приймати до уваги свою слабкість - вона ненавидить будь-який прояв своєї нездатності вплинути на ситуацію і виграти. Перебуваючи в конфлікті, вона методом спроб і помилок учиться переоцінювати свої вміння, шукати недоліки та підбирати алгоритми щодо роботи над ними.

Губристичні риси наявні в характері кожної людини, проте в різній мірі. У той час, як в однієї особи губристична мотивація знаходиться на високому рівні, в іншої вплив прагнення до досягнення досконалості може бути майже непомітним. Проте неможливо уникнути ситуацій, котрі б не змушували людину виражати свої негативні сторони. У силу того, що кожен із нас є носієм тих чи інших губристичних рис, рано чи пізно він реалізує їх. Ю. Козелецький виокремлює дві ситуації, коли людина може задовольнити свої губристичні прагнення: при отриманні влади або ж знайшовши своє місце у соціумі та реалізувавшись як майстер своєї справи (Козелецький, 1991). Для підтримування губристичної мотивації на оптимальному рівні слід не боятися конфліктів, що виникають. Стримування себе у конфліктах і постійний конформізм не дають губристичним прагненням бути реалізованими. Водночас невміння визнати свою неправоту також спотворює губристичні прагнення людини. Ігнорування подібних подій може призвести до фрустрації, а пізніше і до розвитку невротичності в особи, яка намагається стримати себе під час конфлікту. Надмірні ж прояви губристичних рис будуть деструктив- 
ними для неї, адже призведуть лише до зростання губристичних бажань. Мова йде не про свідоме провокування конфліктів, хоча в окремих випадках воно також можливе. Ідеться про поведінку під час конфліктів, коли необхідно не просто проявляти гнучкість, а й задіювати свою хитрість або маніпулятивність. Оскільки в соціальному житті уникнути конфліктів неможливо, виникає думка, що подібні ситуації є не просто природними, а й необхідними для реалізації тих рис, які більшість із нас у собі приховує.

На нашу думку, явище конфлікту невід'ємно пов'язане з губристичною мотивацією, адже особистість із високим рівнем губристичних бажань намагатиметься підвищувати свою самооцінку та панівну позицію за допомогою реалізації бажання вступати у конфлікт задля демонстрації своєї сили, знання або хоробрості. Особливо високий ризик конфлікту може бути в тих соціальних групах, у яких декілька або ж усі учасники мають високий рівень губристичної мотивації. Двом особам із сильним прагненням підвищити свою самооцінку та підтвердити свою важливість важко спілкуватись у силу того, що кожен намагатиметься вийти переможцем у конфлікті. Хоча губристичні риси не завжди можуть усвідомлюватись людиною, проте їх наявність уже може несвідомо підштовхувати до конфлікту, особливо коли обидва опоненти мають бажання отримати домінантну позицію в подібній ситуації. Запорукою ж отримання переваги є не так рівень губристичної мотивації, як уміння користуватися своїми рисами. Самого прагнення влади недостатньо, якщо людина не знає, як правильно поводитися під час конфлікту. Перевагу отримуватиме не той, хто хоче перемогти, а той, хто може спрогнозувати дії опонента та побудувати внутрішній алгоритм поведінки.

Уміння вступати в конфлікти не лише може навчити людину правильно застосовувати та реалізовувати свій губристичний ресурс - це дозволить розвинути в собі флексибільність і не дасть нереалізованим прагненням влади перерости у губристичний синдром - деформацію харак- 
теру особистості, що проявляється в хворобливому прагненні до влади і впевненості у своїй досконалості. Термін «губристичний синдром» не вважається медичним, проте це не скасовує його важливості та вагомості у сучасній психології. Особливостями цього явища, згідно з Д. Оуеном i Д. Девідсоном, є: людина вбачає світ місцем, де можна просто проявити свою силу й енергію; проявляє активність лише для підтримання власного іміджу; відчуває непропорційне занепокоєння через образ i функціональність у суспільстві; мова стає надто завзятою й натхненною, при цьому людина відчуває себе майже месією; з'являється не просто відчуття приналежності до якоїсь групи - людина повністю уособлює себе з тією чи іншою організацією, членом якої вона є в даний момент часу; нерідко використовує займенник «ми», коли говорить про себе; проявляє зайву самовпевненість навіть у тих ситуаціях, де вона недоречна; не приховує свого презирства до інших і намагається його демонструвати якомога яскравіше; вважає себе підзвітною лише перед Богом або вищими силами; проявляє непохитну переконаність у неосудності своїх вчинків; утрачає зв' язок із реальністю; дії стають нерозсудливими й імпульсивними, сама ж людина поводиться занадто невгамовно; стає надто прямолінійною навіть тоді, коли надмірна чесність не є практичною або доречною; виявляє некомпетентність і спирається не на соціальні, а на свої власні норми поведінки.

Губристичний синдром становить небезпеку, адже не дає людині змоги давати адекватну оцінку ситуації, у якій вона зараз перебуває (Davidson, 2009). Це може проявлятись як ерозія влади, коли дії людини стають усе менш продуктивними, а небажання прислухатися до чужих порад призводить до руйнування вже набутих досягнень. Людина не враховує чужу думку, яка не співпадає з їі власною, і настільки впевнена у своїй досконалості, що не визнає будь-яку ймовірність припущення помилок. При цьому деяка ненависть до слабкостей і недоліків зберігається - сама 
думка про ймовірну неповноцінність якогось уміння викликає відразу і змушує сумніватись у собі. У спілкуванні особи з високим рівнем губристичної мотивації нетерплячі й до помилок інших, оскільки оцінюють усіх у межах логічного конструкту «сильний - слабкий». Домінація в системі цінностей людини подібної ідеї вже обмежує її погляди та не дає змоги адекватно аналізувати оточуючий світ.

Звісно, це не єдині симптоми, що супроводжують прояв губристичного синдрому особистості. Спільні риси можна помітити і в нарцисичному розладі, коли людина впевнена у своїй унікальності, а її думки зайняті роздумами про уявні успіхи та перемоги (Свинаренко, 2014). Це також викривлює і реальність, у котрій вона існує, адже у неї виникає відчуття контролю не лише свого, а й чужого життя. Людина намагається контролювати думку оточуючих щодо себе та своїх дій, вважаючи, що її образ є досконалим. Проте причиною цього може слугувати нерозвинуте «Я-ідеальне», через що і створюється хибне уявлення щодо себе (Соколов, 2009). У випадку ж із губристичним синдромом домінуе не просто образ себе як ідеального лідера або митця, а повна підвладність людини своєму бажанню досягнути успіху. Це можна порівняти із залежністю від почуття тріумфу, від тих емоцій, що вона відчуває у разі перемоги або під час керування ситуацією. На відміну від нарцисичного розладу, губристичний синдром не входить до міжнародної класифікації хвороб.

Згідно з Д. Оуеном, губристичний синдром має тенденцію до згасання, коли людина відходить від влади та втрачає своє панівне становище в соціумі (Owen, 2008). Проте подібний перехід може також призвести до зневірення в собі. Людина перестає вважати, що вона здатна хоча б на щось, і на зміну неадекватному завищенню своїх умінь приходить їх заниження. Замість того, щоб намагатися змінити ситуацію, людина просто визнає всі свої не лише пережиті поразки - вона починає «прогнозувати» i нові. Тому в цьому випадку наявність конфлікту в житті губрис- 
тичної особистості особливо важлива. Хоча б невеликі сутички змусять людину не просто відволіктися від поразки, а й дадуть змогу мобілізувати внутрішні ресурси і знову стати продуктивною.

Губристичний синдром не лише змінює бачення світу та поведінку людини, а й впливає на міжособистісне спілкування (Davidson, 2009). Людині з помірним або низьким рівнем губристичної мотивації контактування з особою 3 губристичним синдромом приноситиме дискомфорт і не складатиметься злагоджено. Проте якщо в спілкуванні обидві сторони однаково сильно прагнуть до домінування, то конфліктів не уникнути, адже кожен намагатиметься отримати перевагу і зайняти лідерську позицію. Звісно, винятками є випадки, коли людина силою волі стримує свої губристичні потяги й бажання. Проте, як згадувалося раніше, це доволі важкий і неприємний процес, особливо для людини з яскраво вираженим губрисом. Тому для неї набагато легше і простіше буде вступити в протистояння 3 опонентом. Позитивне відношення до конфліктів - це диференційоване ставлення до них і конструктивне їх вирішення (Дзюба, 2009). Подібне спілкування не призводить ні до чого та не може тривати довго. Воно може дати певний досвід чи слугуватиме кроком до розвитку гнучкості у спілкуванні, але продовжувати подібну комунікацію для людей із високим рівнем губристичної мотивації важко, а для осіб із губристичним синдромом узагалі неможливо.

Губристичні риси присутні не лише в окремих індивідів - вони наявні й в окремих народів. А. Тойнбі стверджував, що цілі народи мають окремі губристичні прагнення (Грицанов, 2003). Проте невміння їх застосовувати на практиці може призвести до руйнування цілої цивілізації. Якщо неправильна реалізація губристичних прагнень може завдати шкоди окремій країні, то некоректне їх застосування тим більше шкідливе для людини. Ігнорування ж своїх негативних сторін є не менш шкідливим уже хоча б тому, що потрапляючи в небезпечну ситуацію, людина 
не зможе відстояти себе, свою думку або навіть урятувати своє або чуже життя. В окремих випадках прояв гніву, хитрості чи здоровий егоїзм можуть допомогти знайти вихід зі складної ситуації. Спроби ж мінімізувати в собі негативні риси або й зовсім позбутися їх ні до чого не призведуть. У найкращому випадку людина зможе просто піддавати рефлексії та контролю кожну свою думку та дію, проте це викликатиме постійне напруження і забиратиме багато сил.

Губристичний синдром може проявитись у будь-якому віці. На відміну від більшості розладів, котрі яскраво помітні в більш зрілому віці, губристична мотивація може даватися взнаки вже у дитинстві, коли дитина прагне привернути до себе якомога більше уваги за допомогою крику чи плачу. Прикладом цього може слугувати ситуація, коли дитина вимагає у батьків придбати їй якусь іграшку. При цьому вона робить це не заради отримання омріяної забавки, а просто для того, щоб дорослі виконали бажання. Іграшка, на відміну від поведінки батьків, не відіграє для дитини важливої ролі. Це здійснюється радше несвідомо, адже у дошкільному віці ніхто не усвідомлює подібні бажання як мотив влади. Проте на основі попереднього досвіду і керуючись певними рисами характеру (амбіційністю, егоїзмом) дитина намагається взяти контроль над ситуацією. У дорослому ж віці бажання отримати своє може перерости у прагнення до переваги або лідерства.

Коли ж конфлікти відсутні або якщо людина займає в конфлікті пасивну позицію, то губристична мотивація залишається нереалізованою. Психологічний дискомфорт зростатиме залежно від того, як довго вона переживає подібне стримування себе. При цьому не варто виключати i ситуацію внутрішнього конфлікту (Вербіна, 2018). Не маючи змоги посперечатися або відчути опозицію, людина починає переживати стан, коли вона вступає у конфлікт із самою собою - з однієї сторони, вона звинувачує себе за подібну слабкість, а з іншої - сердиться на ситуацію, оскільки не знає, як їі вирішити. Можливості не збігаються 3 
бажаннями i, як правило, бажаючи це змінити, людина починає аналізувати ситуацію та намагається поводитись по-іншому. Проте у випадку, коли особа визнає свою безпорадність і полишає всі спроби реалізувати якісь зміни, то подібне рішення стане каталізатором невротичності: зростатимуть тривога, невпевненість у своїх силах, а іноді з'являтимуться і вегетативні порушення. Це лише зайвий раз підтверджує необхідність вступати у конфлікт задля задоволення губристичних прагнень, котрі хоч і різною мірою, проте наявні в кожної особистості.

Щодо самого конфлікту, то це явище є природним для кожної людини, адже усі час від часу потрапляють у суперечку. Він існує стільки ж, скільки існує соціум, і його основною причиною було неспівпадіння в поглядах або ж боротьба за владу чи соціальний статус. Л. М. Карамушка й Т. М. Дзюба стверджують, що конфлікт - це вид соціальної взаємодії між людьми, який виникає на основі залежності один від одного (Дзюба, 2009). Важливу роль при цьому відіграють і вроджені якості людини. Поведінка під час конфліктів може бути різною - від активної протидії конфліктанту до прийняття його позиції, або тривалої їі конфронтації. Уникнення конфлікту неможливе до тих пір, поки людина перебуває в соціумі. Конфлікт не обов' язково може проявлятись у формі відкритого протистояння, а й може бути і прихованим. Проте навіть у таких випадках не вдається проігнорувати внутрішньо-особистісний конфлікт, продукований неспівпадінням бажань і можливостей (Орбан-Лембрик, 2002).

Якщо губристична мотивація людини знаходиться на оптимальному рівні, що не заважає буденній діяльності, вона не ігноруватиме конфлікт. Вона може визнати силу опонента, проте не захоче програвати, тому вдаватиметься до будь-яких засобів, щоб отримати перевагу. Конфлікт для неї не лише захоплююча ситуація - це своєрідний спорт або змагання, успіх у якому дасть змогу задовільнити губрис. Як спортсмен час від часу змушений тренуватися, щоб під- 
тримувати м'язи в хорошому стані, так і губристична особистість удається до конфліктів. Раз за разом вона тренує свої вміння поводитись у конфлікті та прогнозувати його розв'язання. Найкращою ж для неї буде перемога, отримана внаслідок конфлікту з такою ж губристичною особистістю. Конфлікт із такими людьми дозволяє перейняти окремі форми та моделі поведінки, які можна використати в майбутньому. Це саме той випадок, коли подібне може лікувати подібне, чим частіше людина потраплятиме у конфлікти, тим легше їй буде їх переживати без шкоди для себе, прогнозувати вчинки опонента, його слова та вибудовувати тактику й алгоритм урегулювання конфлікту.

\section{Висновки}

На основі аналізу наукових джерел із проблеми губристичної мотивації та отриманих нами даних з'ясовано, що конфлікт є таким самим природним і неминучим явищем, як і губристична мотивація. У людей із яскраво вираженим губрисом існує необхідність потрапляти у конфлікти задля підтримання свого губрису на стабільному рівні шляхом реалізації в конфлікті негативних сторін характеру. Проаналізовано основні симптоми губристичного синдрому та детермінанти його прояву. Виявлено спільні риси з такими психологічними явищами, як нарцисичний розлад і ерозія влади, описано негативний вплив синдрому на соціальне життя та діяльність людини.

\section{Література}

Ващенко I. В., Кляп М. І. Конфліктологія та теорія переговорів. Кииів : Знання, 2012. $402 \mathrm{c.}$

Ващенко I. В., Сударкін О. О. Аналіз впливу оцінки ситуації й оцінки опонента на стратегію вибору поведінки в конфлікті. Вісник Кам'янець-Подільського національного університету ілені Івана Огієнка. Серія: Психологічні науки. Кам'янець-Подільський : ПП «Медобори-2006», 2016. Вип. 8. С. 7-15.

Вербина Г. Г., Русанова Н. А. Внутриличностный конфликт в рамках исследования жизненной перспективы личности. Психология. Ис- 
торико-критические обзоры и совреленные исследования. 2018. Вып. 1А. С. 30-36.

Грицанов А. А. Новейший философский словарь. Минск : Книжный дом, 2003. 1280 с.

Дзюба Т. М., Карамушка Л. М. Психологія управління конфліктами в організації (на матеріалі діяльності освітніх організацій): монографія. Київ - Полтава, 2009. 268 с.

Козелецкий Ю. Человек многомерный: психологические эссе / Пер. с польск. С. А. Чачко. Киев : Лыбидь, 1991. 285 с.

Козьяков Р. В. Психология управления. Москва : МГУП, 2012. 170 с.

Орбан-Лембрик Л. Е. Основи психології управління: монографія. ІваноФранківськ : Плай, 2002. 426 с.

Онуфрієва Л. А., Співак В. І. Теоретико-методологічні аспекти дослідження конфлікту та конфліктності особистості. Збірник наукових праць Кал'янець-Подільського національного університету ілені Івана Огієнка. Серія: Соціально-педагогічна / За ред. Л. П. Мельник, В. І. Співака. Кам'янець-Подільський : ПП «Медобори-2006», 2015. Вип. XXIV. С. 207-220.

Орлянський В. С. Конфліктологія. Київ : Центр учбової літератури, 2007. 159 c.

Саркисов Д. С. Очерки по структурным основам гомеостаза. Москва : Медицина, 1977. 348 с.

Свинаренко Ю. В. Поняття нарцисизм та його характеристика. Психологічне консультування і психотерапія. 2014. Вип. 1-2. С. 265271.

Соколов С. Е. Ценностные корреляты нарциссических проявлений личности: в пределах психической нормы: дис. ... канд. психол. наук: 19.00.01. Хабаровск, 2009. 236 с.

Фоменко К. І. Особистість як суб’єкт подолання кризових ситуацій: психологічна теорія і практика: монографія. Суми : СумДПУ, $2017.540 \mathrm{c}$.

Blaser, A. (1976). Irony and cynicism as defense mechanisms. Confinia Psychiatrica, $19(2), 80-88$.

Davidson, J., \& Owen, D. (2009). Hubris syndrome: An acquired personality disorder? A study of US Presidents and UK Prime Ministers over the last 100 years, Brain, 132 (5), 1396-1406. Retrieved from https://doi.org/10.1093/brain/awp008.

Lewin, K. (1951). Field theory in social science. New York : Harper.

Owen, D. (2008). In Sickness and in Power: Illnesses in Heads of Government During the Last 100 Years. Westport, Connecticut : Praeger Publishers.

Piaget, J. (1951). The Psychology of Intelligence. London : Routledge and Kegan Paul. 


\section{References}

Vashchenko, I. V., \& Kliap, M. I. (2012). Konfliktolohiia ta teoriia perehovoriv [Conflictology and Theory of Conversations]. Kyiv : Znannya [in Ukrainian].

Vashchenko, I. V., \& Sudarkin, O. O. (2016). Analiz vplyvu otsinky sytuatsii y otsinky oponenta na stratehiiu vyboru povedinky v konflikti [Analysis of the impact of the situation of assessment and the opponent's assessment on the strategy of choosing behavior in the conflict]. Visnyk Kamianets-Podilskoho natsionalnoho universytety imeni Ivana Ohiienka. Seriia: Psykholohichni nauku - Newsletter of Kamianets-Podilskyi National Ivan Ohiienko University. Series: Psychology, 8, 7-15. Kamianets-Podilskyi : PP «Medobory-2006» [in Ukrainian].

Verbina, G. G., \& Rusanova, N. A. (2018). Vnutrilichnostnyj konflikt v ramkah issledovanija zhiznennoj perspektivy lichnosti [Intra-personal conflict in the study of the life perspectives of the individual]. Psihologija. Istoriko-kriticheskie obzory $i$ sovremennye issledovanija - Psychology. Historical and critical reviews and current researches, 1A, 30-36 [in Russian].

Gricanov, A. (2003). Novejshij filosofskij slovar' [The newest philosophical dictionary]. Minsk : Knizhnyj dom [in Russian].

Dziuba, T. M., \& Karamushka, L. M. (2009). Psykholohiia upravlinnia konfliktamy $v$ orhanizatsii (na materiali diialnosti osvitnikh orhanizatsii) [Psychology of conflict management in the organization (based on the work of educational organizations)]. Kyiv - Poltava [in Ukrainian].

Kozeleckiy, Ju. (1991). Chelovek mnogomernyj (psihologicheskie jesse) [Multidimensional person (psychological essay)]. Kiev : Lybid' [in Russian].

Koz'jakov, R. V. (2012). Psihologija upravlenija [Psychology of management ]. Moskva : MGUP [in Russian].

Orban-Lembryk, L. E. (2002). Osnovy psykholohii upravlinnia [Fundamentals of Management Psychology]. Ivano-Frankivsk : Plai [in Ukrainian].

Onufriieva, L. A., \& Spivak, V. I. (2015). Teoretyko-metodolohichni aspekty doslidzhennia konfliktu ta konfliktnosti osobystosti [Theoretical and Methodological Aspects of the Study on Conflict and Proneness to Conflict of a Personality]. L.P. Melnyk, V.I. Spivak (Eds.). Zbirnyk naukovykh prats Kamianets-Podilskoho natsionalnoho universytety imeni Ivana Ohiienka. Seria: Sotsialno-pedahohichna - Collection of Research Papers of Kamianets-Podilskyi Ivan Ohiienko National University. Series: Social and Pedagogical Sciences, 24, 207-220. Kamianets-Podilskyi : «Medobory-2006» [in Ukrainian]. 
Orlianskyi, V. S. (2007). Konfliktolopiia [Conflictology]. Kyiv : Tsentr uchbovoi literatury [in Ukrainian].

Sarkisov, D. S. (1977). Ocherki po strukturnym osnovam gomeostaza [Essays of the structural fundamentals of homeostasis]. Moskva : Medicina [in Russian].

Svynarenko, Yu. V. (2014). Poniattia nartsysyzm ta yoho kharakterystyka [The concept of narcissism and its characteristics]. Psykholohichne konsultuvannia i psykhoterapiia - Psychological counseling and psychotherapy, 1-2, 265-271 [in Ukrainian].

Sokolov, S. E. (2009). Cennostnye korreljaty narcissicheskih projavlenij lichnosti: v predelah psihicheskoj normy [Value correlates of narcissistic manifestations of personality : within the mental norm]. Candidate's thesis. Habarovsk [in Russian].

Fomenko, K. I. (2017). Osobystist yak subiekt podolania krizovyh situatsii : psykhologichna teoriia I praktyka [Personality as a subject of crisis situations overcoming: psychological theory and practice]. Sumy : SSPU [in Ukrainian].

Blaser, A. (1976). Irony and cynicism as defense mechanisms. Confinia Psychiatrica, $19(2), 80-88$.

Davidson, J., \& Owen, D. (2009). Hubris syndrome: An acquired personality disorder? A study of US Presidents and UK Prime Ministers over the last 100 years, Brain, 132 (5), 1396-1406. Retrieved from https://doi.org/10.1093/brain/awp008.

Lewin, K. (1951). Field theory in social science. New York : Harper.

Owen, D. (2008). In Sickness and in Power: Illnesses in Heads of Government During the Last 100 Years. Westport, Connecticut : Praeger Publishers.

Piaget, J. (1951). The Psychology of Intelligence. London : Routledge and Kegan Paul.

\section{Брагіна Катерина. Природа губристичної мотивації та розвитку губристичного синдрому крізь призму конфлікту}

\section{АНОТАЦІЯ}

У статті акцентовано увагу на природі губристичної мотивації як компоненті особистості та розглянуто ії через призму конфлікту. Визначено, що губристичні риси характеру, такі як цинізм, егоїзм, амбіційність або хитрість, є невід'ємною складовою будь-якої особистості та, не дивлячись на існуючі стереотипи, їх ігнорування неможливе, а іноді навіть шкідливе для людини, оскільки викликає внутрішній конфллікт і призводить до підвищення психологічного напруження. Проаналізовано сучасні погляди на губристичні прагнення та їх вплив на само- 
сприйняття. Описано особливості прояву негативних рис характеру й утворення губристичного синдрому як деструктора міжособистісної взаємодії й адекватного сприйняття світу, здійснено його порівняльний аналіз із нарцисичним синдромом та ерозією влади. Розкрито симптоматику губристичного синдрому, варіації прояву та способи його запобігання. Описано природу психологічного гомеостазу та його прояви у людей із яскраво вираженим бажанням до отримання влади та прагненням до саморозвитку. Розглянуто переваги зменшення губристичного напруження за допомогою потрапляння особистості в конфлікт, зокрема і провокуючи його свідомо чи несвідомо, а також небезпеку, яку становлять для особистості нереалізовані негативні сторони характеру. Проаналізовано зв'язок прагнення влади та бажання самореалізації зі схильністю людини вступати у конфлікт. 3’ясовано, що вступати у конфлікт важливо заради запобігання зростанню фрустрації через нереалізовану губристичну мотивацію.

Ключові слова: губристична мотивачія, губристичні риси, конфлікт, гомеостаз, нарцисичний розлад.

\section{Брагина Катерина. Природа губристической мотивации и развития губристического синдрома сквозь призму конфликта}

\section{АННОТАЦИЯ}

В статье акцентировано внимание на природе губристической мотивации как компоненте личности и рассмотрена ее сквозь призму конфликта. Определено, что губристические черты характера, такие как цинизм, эгоизм, амбициозность или хитрость, являются неотъемлемой составляющей любой личности и, несмотря на существующие стереотипы, их игнорирование невозможно, а иногда даже вредно для человека, поскольку вызывает внутренний конфликт и приводит к повышению психологического напряжения. Проанализированы современные взгляды на губристические стремления и их влияние на самовосприятие. Описаны особенности проявления отрицательных черт характера и образования губристического синдрома как деструктора межличностного взаимодействия и адекватного восприятия мира, осуществлен его сравнительный анализ с нарциссическим синдромом и эрозией власти. Раскрыто симптоматику губристического синдрома, вариации проявления и способы его предотвращения. Описаны природа психологического гомеостаза и его проявление у людей с ярко выраженным желанием к получению власти и стремлением к самораз- 
витию. Рассмотрены преимущества уменьшения губристического напряжения с помощью попадания личности в конфликт, в том числе и провоцируя его сознательно или бессознательно, а также опасность, которую представляют для личности нереализованные отрицательные стороны характера. Проанализирована связь стремления к власти и желания самореализации со склонностью человека вступать в конфликт. Выяснено, что вступать в конфликт важно ради предотвращения роста фрустрации из-за нереализованной губристической мотивации.

Ключевые слова: губристическая мотивачия, губристические черты, конфликт, гомеостаз, губристический синдром, нарциссическое расстройство. 